\title{
Development of Polycaprolactone/Poly(Vinyl Alcohol)/Clay Microparticles by Spray Drying
}

\author{
Mariana Sato de S. de B. Monteiro',2, Claudia Lopes Rodrigues ${ }^{1}$, Eduardo Miguez, \\ Maria Inês B. Tavares ${ }^{1 *}$
}

${ }^{1}$ Instituto de Macromoléculas Professora Eloisa, Universidade Federal do Rio de Janeiro, Centro de Tecnologia, Bloco J, Cidade Universitária, Ilha do Fundão, Rio de Janeiro, Brazil

${ }^{2}$ Faculdade de Farmácia, Universidade Federal do Rio de Janeiro, Centro de Ciências da Saúde, Bloco L, Cidade Universitária, Ilha do Fundão, Rio de Janeiro, Brazil

Email: *mibt@ima.ufrj.br

How to cite this paper: de B. Monteiro, M.S.de S., Rodrigues, C.L., Miguez, E. and Tavares, M.I.B. (2016) Development of Polycaprolactone/Poly(Vinyl Alcohol)/Clay Microparticles by Spray Drying. Materials Sciences and Applications, 7, 575-592. http://dx.doi.org/10.4236/msa.2016.710048

Received: August 1, 2016

Accepted: September 27, 2016

Published: September 30, 2016

Copyright $\odot 2016$ by authos and Scientific Research Publishing Inc. This work is licensed under the Creative Commons Attribution International License (CC BY 4.0).

http://creativecommons.org/licenses/by/4.0/ (c) (i) Open Access

\begin{abstract}
In this study, nanostructured microparticles was developed with polycaprolactone (PCL), poly(vinyl alcohol) (PVAL) and nanoparticles of the commercial sodium clay NT- $25^{\oplus}$ by using the spray drying technique. The systems obtained were characterized by Nuclear Magnetic Resonance (NMR), Scanning Electron Microscopy (SEM), Fourier Transform Infrared Spectroscopy (FTIR), X-ray Diffraction (XRD), Dynamic Laser Light Scattering (DLS) and Differential Scanning Calorimetry (DSC). The NMR ${ }^{13} \mathrm{C}$ and FTIR techniques showed that both polymers were present in the microparticles and the DSC analysis revealed a small variation in the glass transition temperature of the PCL. The XRD and SEM analyses showed that the microparticles produced were amorphous and had a concave morphology. The NT-25 nanoload reduced the microparticles' size due to the multiple interactions formed in the hybrid nanocomposite material. Therefore, it was possible to develop microparticles by using biodegradable and biocompatible polymers, with different polarities, allowing the incorporation of hydrophilic and hydrophobic materials and enabling the inclusion of otherwise incompatible materials in the same system.
\end{abstract}

\section{Keywords}

Microparticles, Spray Drying, Polycaprolactone, Poly(Vinyl Alcohol), Sodium Clay NT-25

\section{Introduction}

The microparticles are micrometric systems, ranging from $1 \mu \mathrm{m}$ to $1000 \mu \mathrm{m}$, which have been widely studied and employed in the medical and pharmaceutical areas, par- 
ticularly when they are developed with biodegradable polymers, due to its safety and biocompatibility [1]-[5]. Their main advantages are drug protection, mucoadhesion, gastroresistance, and controlled drug release, reducing the dose and frequency of drug administration, obtaining the same therapeutic effect with reduced adverse local and systemic effects and toxicity [6] [7]. Polycaprolactone (PCL) is a biodegradable polymer widely used in the development of microparticles due to its high stability, and permeability, biocompatibility with various drugs, low toxicity and low degradation rate. Its melting temperature varies from $59^{\circ} \mathrm{C}$ to $64^{\circ} \mathrm{C}$, and its glass transition temperature is about $-60^{\circ} \mathrm{C}$ [8]-[11]. Poly(vinyl alcohol) (PVAL) is an amphiphilic semicrystalline polymer, with good interfacial adsorption capacity, and for this reason PVAL has been used in the production of emulsions and microparticles, acting as an emulsifier, to increase the physical stability of microparticles and to encapsulate different drugs. Furthermore, it has low toxicity and it is biodegradable. Its glass transition temperature is around $75^{\circ} \mathrm{C}$ and its melting temperature is around $150^{\circ} \mathrm{C}$ [12]-[15].

A good deal of recent research has been devoted to the development of nanostructured materials containing inorganic fillers dispersed in a polymer matrix. However, these new nanostructured materials must be tested for safety and effectiveness. Among nanoparticles, montmorillonite clay is safe for biomedical applications, since this clay is already used in pharmaceutical preparations [16]-[18]. Bentonite is plastic clay consisting mostly of montmorillonite, a natural clay of the smectite group. It is a type 2:1 lamellar silicate (2 silicon tetrahedrons:1 aluminum octahedron) having the general formula [Mx (Alx-4Mgx) Si8O20 (OH) 4], where $\mathrm{M}$ is a monovalent cation and $\mathrm{x}$ is the isomorphic substitution degree (0.5 to 1.3). Regarding its microstructure, the lamellae have diameters between approximately $100-200 \mathrm{~nm}$ and thickness of $1 \mathrm{~nm}$. This clay is used as a functional excipient in tablets due to its ability to form gels at low concentrations by swelling in water, and it is also used as a binder and disintegrant [19] [20]. For these reasons, bentonite is often employed to produce nanostructured microparticles.

There are several studies in literature that describe the development of polymer/clay system, most of them are nanocomposites. Thus, it is relevant to comprise the clay effect in the PCL and PVAL matrix. The clay dispersion in PCL matrix generally decreases the crystallinity and the crystallite size, because of the dispersed silicate layers that represent a physical barrier and hinder PCL crystal growth. A small clay dispersion, less than $5 \mathrm{wt} \%$, in the PCL matrix is able to reduce its water permeability, increase its stiffness and ductility and improve its thermal stability. Moreover, PCL can exhibit a "pseudo solid-like" behavior at silicate loading greater that $3 \mathrm{wt} \%$, suggesting the maintenance of long-range order domains and a clay orientation in some directions [21]. The clay dispersion in the PVAL matrix can increase the mechanical, thermal and gas barrier properties when its content ranges from $3 \mathrm{wt} \%$ to $10 \mathrm{wt} \%$. It was also noticed that up to $5 \mathrm{wt} \%$ clay loading, clay particles were highly dispersed in PVAL matrix without any agglomeration. However, some agglomerated structures were formed in the polymer matrix above a $7 \mathrm{wt} \%$ clay concentration [22] [23].

Nevertheless, there are no reports of the development of nanosctructured micropar- 
ticles containg PCL, PVAL and clay particles. However, Dong \& Feng developed nanosctructured nanoparticles of Poly(D, L-lactide-co-glycolide)/montmorrilonitte (PLGA/ $\mathrm{MMT}$ ) by emulsion/solvent evaporation method. It was observed that the MMT played the role of a co-emulsifier and the nanoparticles presented a mean size of around 310 $\mathrm{nm}$ [24]. Dyab et al. developed core/shell hybrid organic-inorganic polymer microspheres, using polystyrene and laponite nanoparticles. The formed emulsion showed excellent stability against droplet coalescence and against microparticles coagulation. Generally, the number of microparticles increased and their size decreased with the content of laponite particles, ranging from $1 \%$ to $4 \%$, used in stabilizing and it was attributed to the formation of a rigid layer of the inorganic nanoparticles around the microparticles, increasing the stability [25].

Several methods can be applied to produce polymeric microparticles, such as: 1) Oil/ water emulsion extraction/evaporation method, where a required amount of polymer is dissolved in an organic phase which is emulsified under stirring to form an emulsion and to evaporate the organic phase; 2) Spray dryer technique, where the organic solution with dispersed polymers is sprayed through a nozzle in a spray dryer under different experimental conditions; 3) Solution-enhanced dispersion method, the microparticles were prepared by spraying a solution of polymer in mixture of carbon dioxide and organic solvent into air was termed as rapid exposition of supercritical solutions. As an alternative, the organic polymer solution could be atomized into a vessel containing pressed carbon dioxide; and 4) Hot melt technique, where polymers with low melting point were fabricated into microspheres by hot melt technique [26] [27].

In choosing among them, simplicity, reproducibility and yield should be considered. The emulsification/solvent evaporation technique is widely used in the preparation of microparticles and allows the incorporation of hydrophilic and hydrophobic drugs. However, one of the restrain factors of this technique is the system homogenization, which is typically carried out mildly, for 3 hours at $500 \mathrm{rpm}$, to form the microparticles by the solvent's evaporation at the interface, causing the polymer to precipitate [4] [6]. In this context, this work initially used oil/water emulsion extraction/evaporation method, and then used a high speed mixing to emulsification, in order to achieve a narrow particle size distribution. The spray drying technique has been used after the emulsification process to promote solvent removal and form microparticles, in a shorter time. This method has many advantages, such as good reproducibility, control of particle size and less dependence on the solubility of the active ingredient in the polymer. However, this technique still has limitations, especially for hydrophobic polymers with low melting point, such as PCL [28]-[31].

The main objective of this study was to produce nanostructured microparticles of

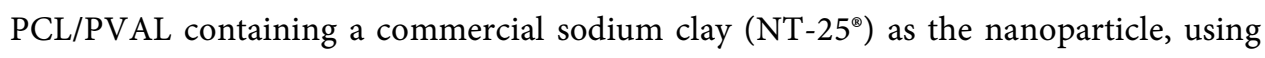
the emulsification process followed by spray drying. The second objective was to characterize the systems by using nuclear magnetic resonance, scanning electron microscopy, infrared spectroscopy, differential scanning calorimetry, X-ray diffraction and dynamic laser light scattering. 


\section{Experimental}

\section{Materials}

The following polymers were used to produce the microparticles:

1) polycaprolactone, obtained from Sigma Aldrich, with melt index of $1.9 \pm 0.3 \mathrm{~g} / 10$ min (ASTM D-1238), density of $1.14 \mathrm{~g} / \mathrm{cm}^{3}$ and numerical molar mass (Mn) of $80,000 \mathrm{~g} / \mathrm{mol}$;

2) poly(vinyl alcohol), obtained from Vetec, with hydrolysis degree of $88.3 \%$ and numerical molar mass $(\mathrm{Mn})$ of $4060 \mathrm{~g} / \mathrm{mol}$; and

3) sodium clay NT-25, obtained from Bentonit União Nordeste. This clay is a natural calcium bentonite, without the presence of organic modifier, with surface area of $139 \mathrm{~m}^{2} \cdot \mathrm{g}^{-1}$ and cation exchange capacity (CEC) of $0.8 \mathrm{meq} / \mathrm{g}$. It has inter-layer spacing (d 001) equal to $1.51 \mathrm{~nm}$ [32].

The solvent used was chloroform P. A., obtained from Tedia Brasil. The other reagents employed were of analytic grade and were used as received.

\section{Methods}

\section{Preparation of microparticles}

In the first step, in order to make a primary emulsion $5 \% \mathrm{w} / \mathrm{v}$ of PCL was dissolved in chloroform, under magnetic stirring with stir bar of $2.5 \mathrm{~cm}$, at $500 \mathrm{rpm}$, for 24 hours, at $25^{\circ} \mathrm{C}$, until former a clear solution. In the second step, to be used as outer aqueous phase $5 \% \mathrm{w} / \mathrm{v}$ of PVAL was dissolved in distilled water and stirred with a magnetic stirrer of $2.5 \mathrm{~cm}$, at $500 \mathrm{rpm}$, at $60^{\circ} \mathrm{C}$ until completely dissolved. Then, when the temperature was around $25^{\circ} \mathrm{C}$, the aqueous phase was poured into the organic phase, under magnetic stirring; at $800 \mathrm{rpm}$, for 30 minutes, in a flask of $500 \mathrm{ml}$, to form an initial emulsion system. The systems were prepared in triplicate and separated into three fractions. The initial magnetic stirring is still a technique applied for the development of microparticles, in the research field.

The first fraction was submitted to spray drying in an LM 1.0 MSD (mini spray dryer) (LabMaq do Brasil, São Paulo, Brazil), under the following operating conditions: feed flow of $3.3 \mathrm{ml} / \mathrm{min}$; air flow of $500 \mathrm{l} / \mathrm{h}$; air pressure of $3 \mathrm{kgf} / \mathrm{cm}^{2}$, inlet temperature of $110 \pm 4^{\circ} \mathrm{C}$; outlet temperature of $95 \pm 5^{\circ} \mathrm{C}$; atomizer nozzle diameter of $1.0 \mathrm{~mm}$; and vacuum formation rate of $0.6 \mathrm{~m}^{3} / \mathrm{min}$. This first sample was named PCL/PVAL.

The second fraction was homogenized using an Ultra-Turrax ${ }^{\circledast}$ (UT) high-power homogenizer for 2 minutes at $16,000 \mathrm{rpm}$, at $25^{\circ} \mathrm{C}$, forming a more stable emulsion. Then this emulsion was dried using the same spray dryer, with the conditions described above. This sample was named PCL/PVAL/UT.

For the third fraction, $3 \% \mathrm{w} / \mathrm{w}$ of sodium NT-25 clay was added to the organic phase, followed by 48 hours of stirring, at $25^{\circ} \mathrm{C}$. Then, the aqueous phase was dispersed in the organic phase containing the clay, and this mixture was homogenized in the UT for 2 minutes at $16,000 \mathrm{rpm}$, forming an emulsion. This emulsion was dried using the mini spray dryer under the conditions described above. This sample was named PCL/PVAL/ NT-25/UT. The clay was not sprayed in the system that are used the magnetic agitation, because the system did not form a homogenous emulsion with magnetic stirring. 
The concentration of PCL, PVAL, clay and solvents used were chosen according to previous studies in the literature, since the main objective of this work was to verify whether the proposed method was effective in developing nanostructured particles. However, it is recommended to developed stable microparticles, by the emulsion method, using around 2 to $10 \mathrm{wt} \%$ of polymer in the organic phase. The variation in PVA concentration will affect the stability of emulsion and the size of the microspheres. More uniform sized and small microspheres are obtained on the concentration of PVA, varying from $2.5 \mathrm{wt} \%$ to $5 \mathrm{wt} \%$ [33].

Clay is a stabilizing, supending, adsorvent and viscosity increasing agent and the amount recommended for NT-25 clay acts as a stabilizing agent, ranging from $0.5 \%$ to 5\% [18]-[20]. Besides, the PCL nanocomposites developed with NT-25 clay, ranging from $1 \%$ to $5 \%$, showed that $3 \mathrm{w} / \mathrm{w} \%$ of NT-25 achieved the best dispersion in the polymer matrix [34].

\section{Characterization of the microparticles}

\section{Nuclear magnetic resonance}

The ${ }^{13} \mathrm{C}$ NMR analyses were performed at $300 \mathrm{MHz}$ with a Varian Mercury VX 300 spectrometer. The procedures used to obtain the spectra and analytic parameters are described below: For ${ }^{13} \mathrm{C}$ NMR analysis, the PCL, PVAL and the microparticles were prepared in the following solutions: $100 \mathrm{mg}$ of PCL in $2 \mathrm{ml}$ of deuterated tetrachloroethane (TCE); $100 \mathrm{mg}$ of PVAL in $2 \mathrm{~mL}$ of deuterated water $\left(\mathrm{D}_{2} \mathrm{O}\right)$; and approximately $100 \mathrm{mg}$ of microparticles in $2 \mathrm{ml}$ of deuterated dimethyl sulfoxide (DMSO). The samples were placed in a NMR tube (10 $\mathrm{mm}$ in diameter) and then in a $10 \mathrm{~mm}$ probe.

The parameters used in the ${ }^{13} \mathrm{C}$ analysis were observation frequency of $75 \mathrm{MHz}$, analysis temperature of $90^{\circ} \mathrm{C}, 8000$ accumulations, pulse width applied $\left(90^{\circ}\right)$ equal to $23.4 \mu \mathrm{s}$, interval between pulses of 1 second and spectral window of $18,000 \mathrm{~Hz}$. The peak areas in the microparticles' ${ }^{13} \mathrm{C}$ spectra were integrated, allowing calculation of the proportion of each polymer in the developed system [35] [36].

\section{Infrared spectroscopy}

The FTIR analyses were performed in attenuated total reflection mode (ATR), in order to identify the main functional groups, using a Thermo Scientific Nicolet ${ }^{\mathrm{TH}} \mathrm{iS}^{\mathrm{Ta}} 10$ FTIR spectrometer, in a scanning range of $4000-675 \mathrm{~cm}^{-1}$, collection time of 25 seconds, with 128 scans and normal resolution spectrum. The reference material (calibration) used in the ATR analysis was a geranium crystal and the samples were placed on both sides of the crystal [37] [38].

\section{$\mathrm{X}$-ray diffraction}

The X-ray diffraction evaluations of the crystalline structure and dispersion of the clay in the nanoparticles were carried out at room temperature with a Rigaku Miniflex X-ray diffractometer, with emission of $\mathrm{CuK} \alpha$ radiation $(\lambda=1.5418 \AA$ ), $40 \mathrm{KV}$ and 30 $\mathrm{mA}$. The diffraction patterns were collected in a scanning range of $2^{\circ}<2 \theta<30^{\circ}$, for 3 seconds at steps of $0.05^{\circ}$ [37] [38].

\section{Differential scanning calorimetry}

The miscibility between the PCL and PVAL was evaluated by DSC using a TA In- 
struments Q1000 V9.8 Build 296 calorimeter, operating under $\mathrm{N}_{2}$ flow of $50 \mathrm{~mL} / \mathrm{min}$, with a heating rate of $10^{\circ} \mathrm{C} / \mathrm{min}$, in the range from $-70^{\circ} \mathrm{C}$ to $150^{\circ} \mathrm{C}$ for PCL, from $25^{\circ} \mathrm{C}$ to $270^{\circ} \mathrm{C}$ for PVAL and $-70^{\circ} \mathrm{C}$ to $260^{\circ} \mathrm{C}$ for the PCL/PVAL microparticles [37].

\section{Scanning electron microscopy}

The surface texture and shape of the microparticles were observed by SEM with a Jeol JSM-5610 LV scanning microscope. The samples were previously sputtered with gold for 20 seconds (Denton Vacuum Desk II) and the photomicrographs were obtained using voltage of $20 \mathrm{kV}$ and 4000 to $8000 \mathrm{x}$ magnification [11] [12].

\section{Dynamic laser light scattering}

The average diameter of the particles was determined after their dispersion in distilled water at a concentration of 1:1000. The diameter was measured in a Brookhaven multi-angle particle sizer, with detection angle of $90^{\circ}$, in a quartz cell with $1 \mathrm{~cm}$ optical path, and the data were integrated using the MAS OPTION software [11] [12].

\section{Results and Discussion}

Nuclear magnetic resonance is a spectroscopy that analyzes the nuclear spin movement and behavior in the presence of a strong external magnetic field. From this spectroscopy it is allowed to analyze different nuclei in a sample, employing a specific sequence of pulses. The NMR spectroscopy is widely used to study the chemical assignments and molecular dynamics of various types of materials detected through the intermolecular interaction, dispersion and the distribution of their components [37]-[39]. The solution ${ }^{13} \mathrm{C}$ NMR spectrum allows identifying the different types of carbon in samples, facilitating study of the microstructure of microparticles [40] [41].

The ${ }^{13} \mathrm{C}$ NMR solution spectra of PCL, PVAL and microparticles produced are presented in Figure 1. Analyzing the ${ }^{13} \mathrm{C}$ NMR solution spectrum of the PCL, carbonyl

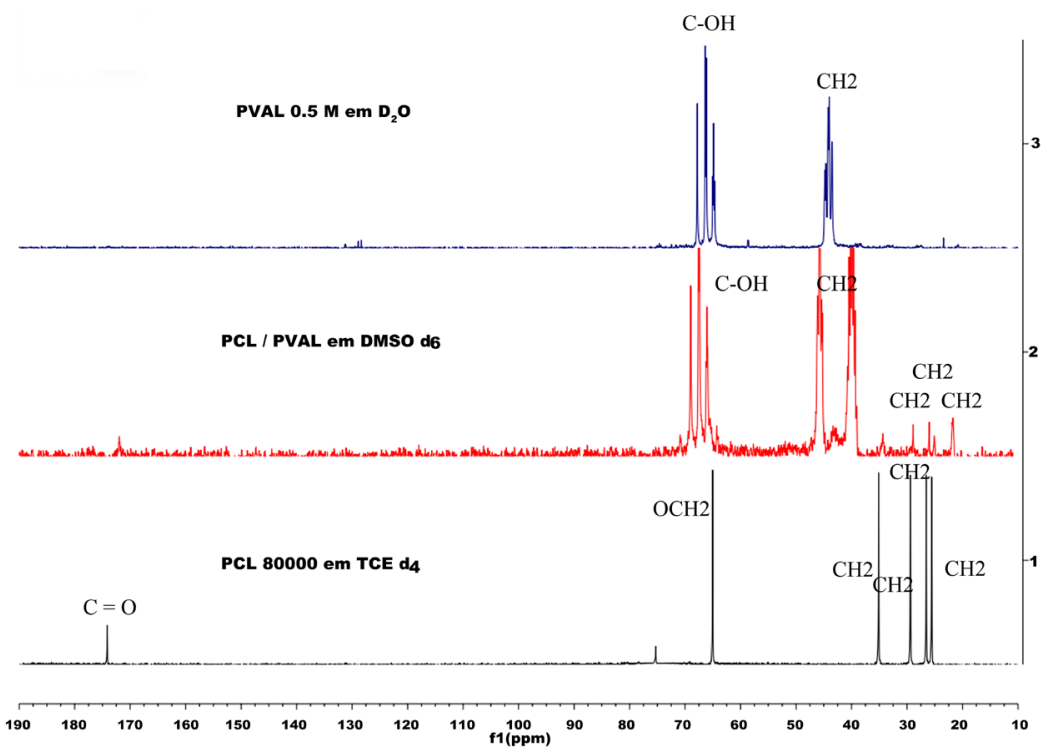

Figure 1. NMR spectra of ${ }^{13}$ carbon in solution of the polymers PCL, PVAL and PCL/PVAL microparticles. 
group presents its chemical shift located at $174 \mathrm{ppm}$, the $\mathrm{OCH}_{2}$ group (I) at $65.2 \mathrm{ppm}$, the $\mathrm{CH}_{2}$ group (II) at $35.2 \mathrm{ppm}$, the $\mathrm{CH}_{2}$ group (III) at $29.5 \mathrm{ppm}$, the $\mathrm{CH}_{2}$ group (IV) at $26.7 \mathrm{ppm}$ and the $\mathrm{CH}_{2}$ group (V) at $25.7 \mathrm{ppm}$ [42]. The spectrum of the PVAL showed two signals in the one referrer to the $\mathrm{C}-\mathrm{OH}$ group located at $68.4 \mathrm{ppm}$ and the other one due to the $\mathrm{CH}_{2}$ group at $45.3 \mathrm{ppm}$ [43].

The ${ }^{13} \mathrm{C}$ NMR solution spectrum of the microparticles presented peaks characteristic of both PCL and PVAL. The peaks with chemical shifts at $174 \mathrm{ppm}, 35.2 \mathrm{ppm}, 29.5$ ppm, $26.7 \mathrm{ppm}$ and $25.7 \mathrm{ppm}$ correspond to the carbonyl, $\mathrm{CH}_{2}$ group (II), $\mathrm{CH}_{2}$ group (III), $\mathrm{CH}_{2}$ group (IV) and $\mathrm{CH}_{2}$ group (V) of the PCL, respectively. In turn, the peaks with chemical shifts located at $68.4 \mathrm{ppm}$ and $45.3 \mathrm{ppm}$ correspond to the $\mathrm{C}-\mathrm{OH}$ and $\mathrm{CH}_{2}$ PVAL groups, respectively. However, the peaks corresponding to the chemical shift of the functional groups of the PCL were less intense than the peaks of the PVAL, due to the lower ratio of PCL in the microparticles.

By integrating the areas under the peaks of the microparticles in the NMR ${ }^{13} \mathrm{C}$ spectra, it was possible to confirm the proportion of each polymer in the system, as reported in Table 1. The proportion of PCL in the system was about 10\%, with PVAL making up the other $90 \%$. All the samples produced presented similar results. The proportion of each polymer in the systems can be correlated with its thermal properties and with the processing method used.

\section{DSC Measurments}

PCL has a glass transition temperature $(\mathrm{Tg})$ of around $-70{ }^{\circ} \mathrm{C}$ and melting temperature $(\mathrm{Tm})$ of about $55^{\circ} \mathrm{C}$ while PVAL has a $\mathrm{Tg}$ near $75^{\circ} \mathrm{C}$ and $\mathrm{Tm}$ of about $150^{\circ} \mathrm{C}$, as can be seen from analyzing the DSC spectra in Figure 2. In the spray drying process, the incoming air temperature was $110^{\circ} \mathrm{C}$, set at this level to promote proper dehydration of the material. PVAL has a higher melting point than the air temperature used in the drying process, so it was not in the melted state during the drying process, causing it to have lower propensity to stick together or adhere to the surfaces of the drying chamber. In contrast, PCL's melting point is lower than this air temperature, so it was in the melted state during the drying process, causing a greater tendency to stick and form aggregates. This phenomenon explains the higher proportion of PVAL than PCL in the microparticles, as can be seen from the ${ }^{13} \mathrm{C}$ spectra obtained by NMR [12] [13].

The DSC analysis Figure 2 was used to determine the miscibility of the polymer system developed. While it was not possible to observe the Tg of the PCL due to the limitations of the DSC instrument, the Tg of the pure PVAL was about $72^{\circ} \mathrm{C}$. The micro-

Table 1. Chemical shift and area under the peaks of the ${ }^{13} \mathrm{C}$ spectra of PCL/PVAL microparticles.

\begin{tabular}{cccc}
\hline${ }^{13} \mathrm{C}$ of PCL/PVAL Microparticles & Chemical Shift & Normalized Peak Area & Absolute \\
\hline $\mathrm{CH}_{2}$ (PCL) & $36.69-16.47$ & 8.34 & 55,429 \\
$\mathrm{CH}_{2}$ (PVAL) & $48.53-43.08$ & 41.72 & 277,114 \\
$\mathrm{C}-\mathrm{OH}$ (PVAL) & $73.77-61.26$ & 53.28 & 353,866 \\
$\mathrm{C}=\mathrm{O}$ (PCL) & $174.34-168.63$ & 1.00 & 6642 \\
\hline
\end{tabular}




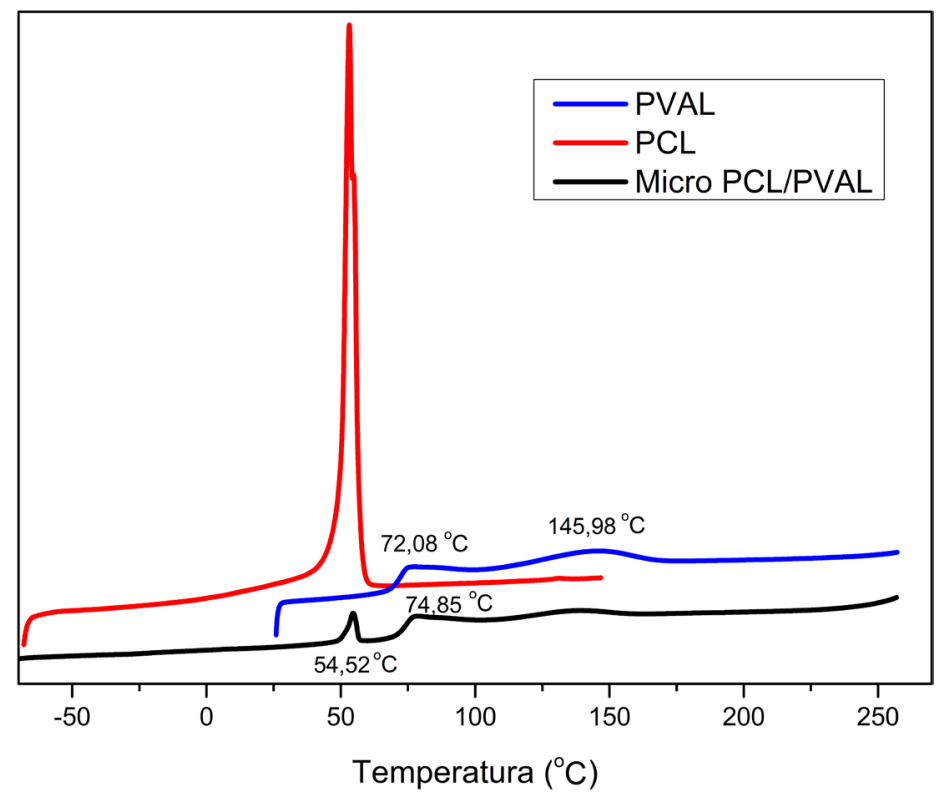

Figure 2. DSC curves for PCL, PVAL and PCL/PVAL microparticles.

particles presented a peak related to melting of the PCL crystals at $54.52^{\circ} \mathrm{C}$ and a plateau referring to the $\mathrm{Tg}$ of the PVAL at $74.85^{\circ} \mathrm{C}$. Because of this small change of the $\mathrm{Tg}$, it was not possible to confirm that interaction occurred between the polymers. Systems formed of compatible polymers have $\mathrm{Tg}$ values that are shifted in relation to the values of the pure polymers, with this shift being greater than the stronger specific interactions of each polymer are. Therefore, if an interaction occurred between the polymers, it was not a strong one, since the shift of the $\mathrm{Tg}$ was not significant [44]. Besides this, the $\mathrm{Tg}$ of a miscible mixture depends on the composition of each polymer in the mixture, so a higher PVAL content in the mixture causes the Tg value of the microparticles to be more shifted toward the Tg of the pure PVAL.

\section{Infrared Spectroscopy}

The FTIR ATR analysis supplies important information, such as the chemical composition, configuration and conformational structure [37]. Therefore, we used this technique to evaluate the chemical groups of the polymers. Figure 3 presents the FTIR spectrum of the PCL, showing the main absorption bands: in the $500-900 \mathrm{~cm}^{-1}$ range, referring to the $\mathrm{CH}_{2}$ deformation; $900-1000 \mathrm{~cm}^{-1}$ range, due to the $\mathrm{C}-\mathrm{O}-\mathrm{C}$ symmetric deformation; $1000-1100 \mathrm{~cm}^{-1}$ range, attributed to the $\mathrm{C}-\mathrm{C}$ deformation; $1100-1150$ $\mathrm{cm}^{-1}$ range, referring to the $\mathrm{C}-\mathrm{O}$ deformation; at $1168 \mathrm{~cm}^{-1}$, associated with the symmetric $\mathrm{O}-\mathrm{C}-\mathrm{O}$ vibration; at $1241 \mathrm{~cm}^{-1}$, related to the asymmetric $\mathrm{C}-\mathrm{O}-\mathrm{C}$ vibration; at $1724 \mathrm{~cm}^{-1}$, referring to the carbonyl vibration; and at $2931 \mathrm{~cm}^{-1}$, attributed to the asymmetric $\mathrm{CH}_{2}$ vibration [43] [45]. In turn, the FTIR spectrum of the PVAL has bands at $3440 \mathrm{~cm}^{-1}$, referring to the stretching of the $\mathrm{OH}$ group; $2927 \mathrm{~cm}^{-1}$, referring to the vibration of the $-\mathrm{CH}_{3}$ group; $1731 \mathrm{~cm}^{-1}$, referring to the $-\mathrm{O}=\mathrm{C}-\mathrm{OR}$ vibration; 1087 $\mathrm{cm}^{-1}$, due to the $-\mathrm{C}-\mathrm{O}-\mathrm{C}$ vibrations; and $844 \mathrm{~cm}^{-1}$, referring to the $-\mathrm{CH}$ vibration [46]. The FTIR spectrum of the NT-25 exhibits bands at $3625 \mathrm{~cm}^{-1}$ and $3402 \mathrm{~cm}^{-1}$, referring 


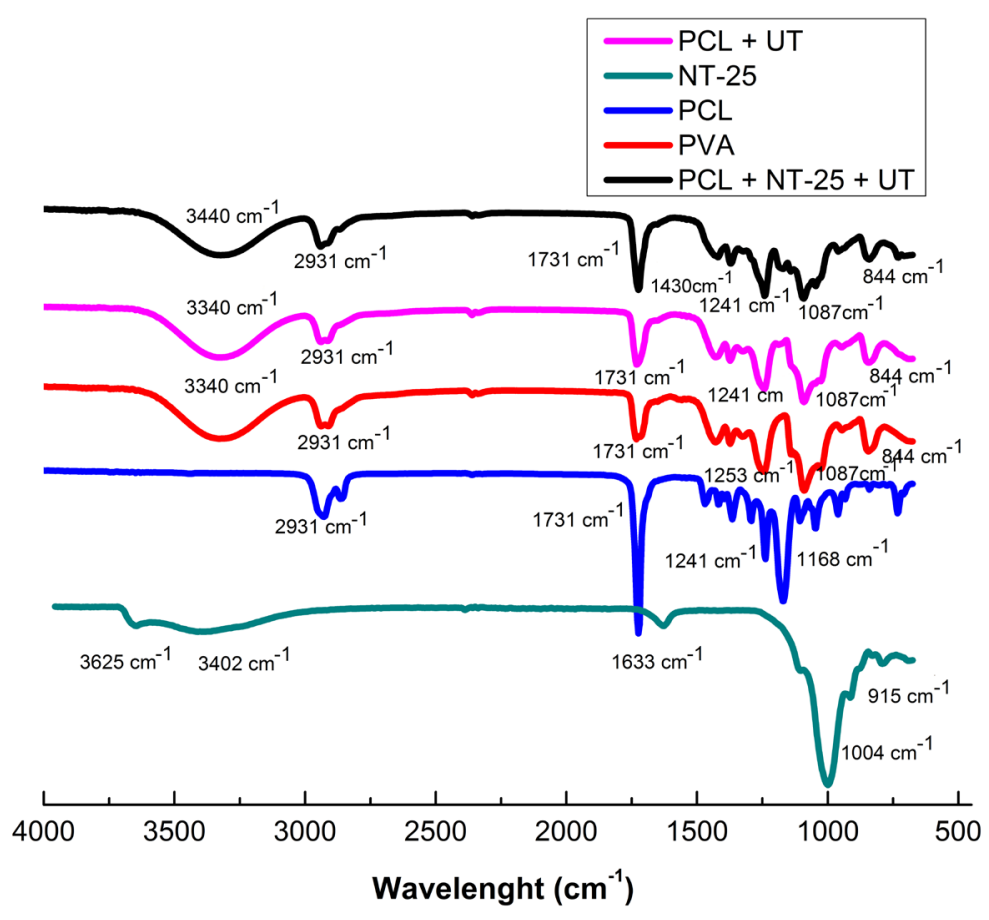

Figure 3. Overlapping infrared spectra of PCL, PVAL, NT-25 clay and microparticles of PCL/PVAL/UT and PCL/PVAL/NT-25/UT.

to the axial stretching vibrations of the - $\mathrm{OH}$ groups of adsorbed water between lamellae, since untreated clays swell more in water, resulting in broadening of the peaks in question, $1633 \mathrm{~cm}^{-1}$, referring to the angular deformation of hydration water, 1004 $\mathrm{cm}^{-1}$, referring to the Si-O-Si bonds and $915 \mathrm{~cm}^{-1}$, referring to the octahedral layer of aluminosilicate [47].

The microparticles produced presented characteristic bands of both PCL and PVAL, as follows: at $844 \mathrm{~cm}^{-1}$, referring to the $-\mathrm{CH}$ vibration of PVAL; at $1087 \mathrm{~cm}^{-1}$, due to the -C-O-C vibration of PVAL, at $1731 \mathrm{~cm}^{-1}$, referring to the $-\mathrm{O}=\mathrm{C}-\mathrm{OR}$ vibration of PVAL; at $3440 \mathrm{~cm}^{-1}$, referring to the stretching of the $\mathrm{OH}$ group of PVAL, at $1241 \mathrm{~cm}^{-1}$, related to the asymmetric C-O-C vibration of PCL; and at $2931 \mathrm{~cm}^{-1}$, attributed to the asymmetric $\mathrm{CH}_{2}$ vibration of PCL. It was not possible to see any peaks characteristic of the clay in the PCL/PVAL/NT-25/UT sample, because the clay's peaks were superimposed on those attributed to the vibrations of the PCL and PVAL.

The NMR ${ }^{13} \mathrm{C}$ and FTIR techniques showed that the two polymers were present in the microparticles, because the main functional groups of both were detected in the samples. The DSC analysis showed only a small variation of the Tg, so it was not possible to confirm an interaction between the PCL and PVAL. However, Kesel and collaborators developed polymer blends of PCL/PVAL, in the form of films, by the solvent evaporation method. The measurement of spin-lattice relaxation time of the ${ }^{1} \mathrm{H}$ nucleus, using solid-state cross-polarization NMR, demonstrated the occurrence of some physical interactions between the PCL and PVAL and showed that the polymers were finally dispersed in the sample and were compatible at a scale of $60-90 \mathrm{~nm}$ [13]. 


\section{X-Ray Diffraction}

$\mathrm{XRD}$ is one of the leading methods to characterize polymers, because it can supply information on the crystalline or amorphous state of the material and its structure by means of the position, shape and intensity of the peaks attributed to the atomic vibrations [37] [38]. Crystals contain ordered arrangements of molecules and atoms, maintained in contact by non-covalent interactions, while an amorphous solid is characterized by the disorderly or random state of its molecules [48].

Figure 4 shows the X-ray diffraction pattern, for $2 \theta$ ranging from 2 to $30^{\circ}$, of the PCL, PVAL, NT-25 and microparticles. The PCL has a pattern with two reflection peaks, at $2 \theta=21.4^{\circ}$ and $23.8^{\circ}$, with basal spacing of 0.412 and $0.325 \mathrm{~nm}$, corresponding to the (110) and (220) of the crystal growth planes, in orthorhombic form [49]. The PVAL Figure 3 presents an intense reflection peak at $2 \theta=19.4^{\circ}$, which corresponds to a basal spacing of $0.457 \mathrm{~nm}$ [50]. The diffractograms of the NT-25 clay are presented in Figure 4 and Figure 5, with interlayer spacing (d 001) equal to $1.51 \mathrm{~nm}$ [32].

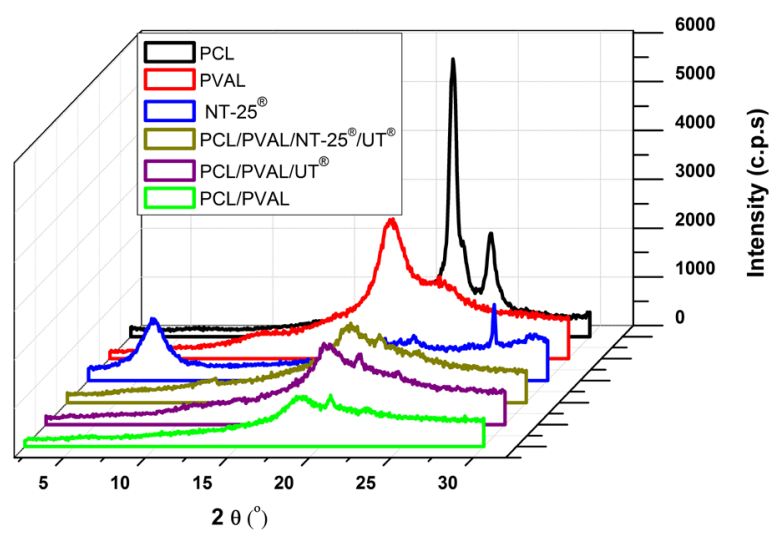

Figure 4. X-ray diffraction patterns of PCL, PVAL, NT-25 clay, and microparticles of PCL/PVAL, PCL/PVAL/UT and PCL/PVAL/NT-25/UT.

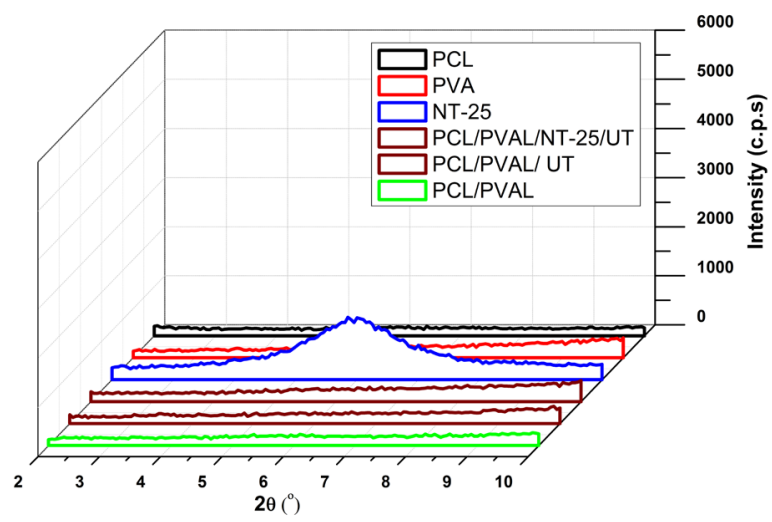

Figure 5. X-ray diffraction patterns, expanded in the region of $2 \theta=0$ to $10^{\circ}$, of PCL, PVAL, NT-25 clay and microparticles of PCL/PVAL, PCL/PVAL/UT and PCL/PVAL/NT-25/UT. 
The microparticles produced did not present crystallographic planes corresponding to PCL or PVAL, indicating a loss of crystallinity and the formation of amorphous microparticles, as can be seen in Figure 4. In the microparticles composed of PCL/PVAL/ NT-25/UT, it was not possible to observe the characteristic peak of clay in the region of $2 \theta=7.5$ (Figure 5), indicating a good dispersion of this nanoload in the polymer matrix. Besides that, in our previous study it was confirmed that the PCL/NT-25 nanocomposite achieved a predominantly intercalated/exfoliated morphology and the thermogravimetric analysis was used to determine the percentage of NT-25 nanoload incorporated in the PCL matrix and the following weight fraction were found: $3.27 \% \mathrm{w} / \mathrm{w}$ [34]. The loss of crystallinity can be attributed to the spray drying process, producing an amorphous material and this behavior has been observed by various authors in studies of the use of polymers and their nebulization by spray drying [51]-[53].

As previously mentioned, the clay addition in the polymeric systems, such as nanoparticles, can influence its morphology, crystallinity, and their thermal and rheological properties. In addition, some studies have reported that the incorporation of high amount of clay decreased the drug encapsulation efficiency [54]. Others studies demonstrated that polymer molecular motions is hindered, since sodium clay swells to about 12 times its original volume in water, increasing the viscosity, by the presence of clay nanoparticles and this behavior is more pronounced at $10 \mathrm{w} / \mathrm{w} \%$ of clay [55]. The system viscosity is very relevant when the spay dryer is used; since a large amount of clay can interfere the system spraying and a low concentration of clay may not be enough to stabilize the particles.

\section{Dynamic laser light scattering}

Dynamic laser light scattering (DLS) analysis supplies information on the diameter of the particles in suspension, by measurement of the hydrodynamic diameter $(Z)$ versus volume mean diameter [56]. Figure 6 shows the distribution of the particles' diameters. It can be seen that the microparticles that were not processed in the UT apparatus (PCL/PVAL) have three main populations: the first with mean diameter of 57.6

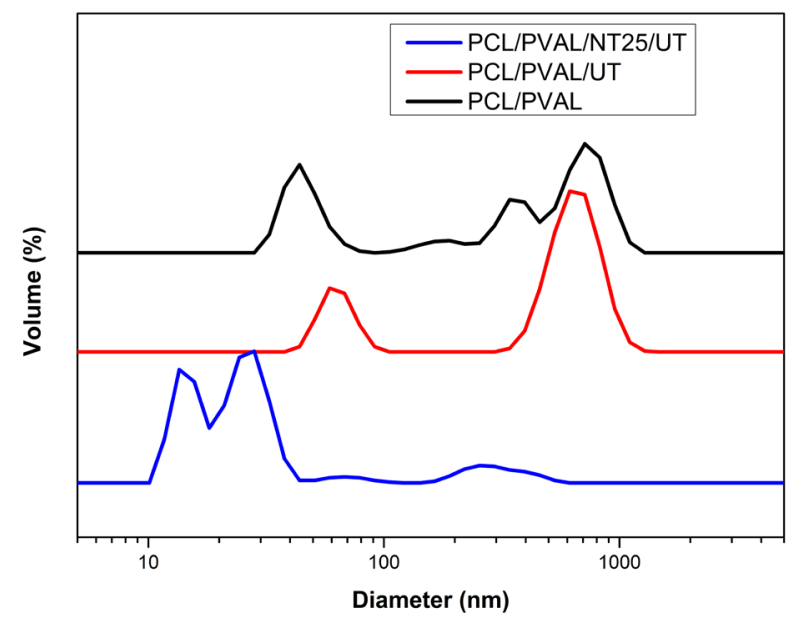

Figure 6. Particle size distribution by DLS: microparticles of PCL/PVAL, PCL/PVAL/UT and PCL/PVAL/NT-25/UT. 
$\mathrm{nm}$, the second with mean diameter of $185.7 \mathrm{~nm}$ and the third with mean diameter of $700.3 \mathrm{~nm}$. However, this third population has greater intensity, indicating it represents the main part of the sample. The microparticles submitted to UT processing (PCL/ PVAL/UT) have two populations, the first with mean diameter of $66.9 \mathrm{~nm}$ and the second with mean diameter of $578.2 \mathrm{~nm}$, which accounted for the largest portion of the sample. Finally, the PCL/PVAL microparticles with NT-25 nanoload and processed in the UT present two populations, the first with mean diameter of $75.8 \mathrm{~nm}$ and the second, which made up the largest part of the sample, with mean diameter of $350.8 \mathrm{~nm}$.

This result was expected and may be related to the use of Ultra-Turrax ${ }^{\oplus}$, since UT is a high-performance dispersing machine, which increases the system homogeneity and causes a greater shearing of emulsions and suspensions, reducing the particle size. In addition, the PCL/PVAL/NT-25 microparticles showed smaller diameter, indicating that the NT-25 nanoload might have contributed to this phenomenon, once the NT-25 have an average diameter of $211 \mathrm{~nm}$ [57]. This result can be related to the fact that montmorillonite clays act as co-emulsifiers, helping the process of forming microparticles by reducing the interfacial tension and keeping the droplets more dispersed [58]-[61]. Besides this, NT-25 also likely acted as an adjuvant during the spray drying process, by reducing the tendency of the polymer suspension to adhere to the interior surfaces of the dryer [62]. The inclusion of clay in this system might have made the suspension more stable and homogeneous, favoring the emulsion's passage through the spray dryer and producing microparticles with smaller diameters.

Although the characteristic peaks of NT-25 clay become superimposed in the FTIR of PCL/PVAL/NT-25 microparticles, the particle size study by DLS can be a strong indication of the clay presence in the system. Since in the PCL/PVAL/NT-25 microparticles there was a strong reduction in the size of particles, while all other parameters remained constants, such as polymers and clay concentration, temperature, solvent, and production method.

Besides, it may consider that the PCL concentrations, PVAL and clay were suitable for the microparticles development. However, it is not interesting works with a less PCL concentration since using the ratio of 50:50 of PCL/PVAL, the percentage of PCL /PVAL in the system was 10:90. The $3 \%$ of clay amount was appropriate, once the formulation was sprayed by spray dryer, reduced the size of microparticles, acting as a stabilizing agent. The complete removal of the solvents was confirmed by FTIR, once the spectrum did not show any characteristics bands of solvent.

\section{Scanning electron micrography}

The SEM analyses Figure 7 indicated the formation of non-spherical microparticles containing concavities and invaginations. The microparticles' surfaces were smooth, without roughness or porosity. This morphology can be attributed to the spray drying conditions, because this technique relies on high temperature and rapid drying kinetics, causing high vapor pressure in the droplets. The fact that the drying temperature of the droplets is higher than the solvent's boiling point keeps the droplets inflated, generating particles with hollow and spherical morphology [51]. Besides this, the indication of the 


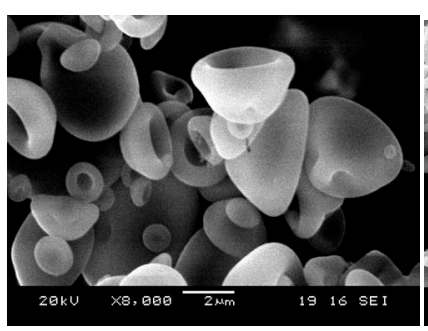

(a)

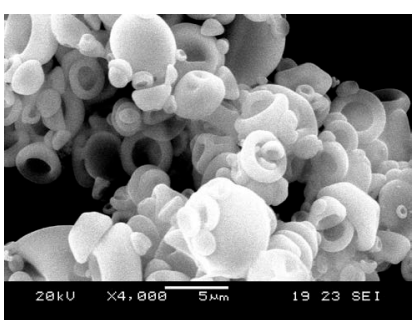

(b)

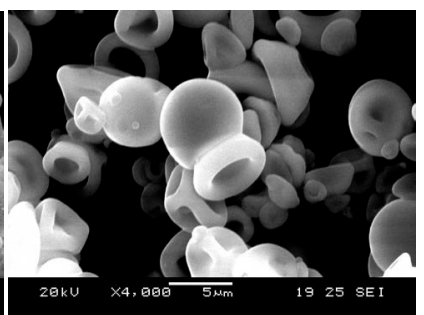

(c)

Figure 7. Photomicrographs by SEM of PCL/PVAL/NT-25/UT (a) PCL/PVAL; (b) and PCL/ PVAL/ UT; (c) respectively.

encapsulating capacity of a polymer is given by the degree of integrity and porosity of the particles formed. Although the particles produced here had some surface depressions or irregularities, we did not find the occurrence of microfissures and cracks on their surface, suggesting good capacity to encapsulate active ingredients [63].

\section{Conclusion}

In this study, we obtained innovative microparticles of PCL/PVAL and PCL/PVAL/ NT-25, using emulsification techniques followed by spray drying. The DSC analysis showed a small variation in the $\mathrm{Tg}$, but it was not possible to confirm the occurrence of interaction between the polymers. Besides this, the XRD study showed that amorphous systems were formed, which was interesting from a technological standpoint, because this could increase the bioavailability of the drug molecules included in the system. The nanoparticle, the commercial clay NT-25, helped to reduce the size of the microparticles formed by acting as a co-emulsifier. The SEM images revealed microparticles with concave morphology, without surface depressions and irregularities. These systems have the advantage of being formed by biocompatible and biodegradable polymers, PCL and PVAL, which have distinct polarities, facilitating the inclusion of both hydrophilic and hydrophobic active ingredients. Furthermore, it is possible to disperse the sodium montmorillonite clay, promoting the reduction of the particles size.

\section{References}

[1] Pereira, M.R., Cruz, L., Ré, M.I. and Gutteres, S.S. (2006) Micropartículas secas contendo Fármaco Modelo Lipofílico preparadas a partir de suspensão Aquosa: Estudo de Formulação. Acta Pharmaceutical Bonaerense, 25, 198-205.

[2] Barbanti, S.H., Zavaglia, C.A.C. and Duek, E.A.R. (2005) Polímeros Bioreaborvíveis na Engenharia de Tecidos. Polímeros, 15, 13-21. http://dx.doi.org/10.1590/S0104-14282005000100006

[3] Lu, Y. and Chen, S.C. (2004) Micro and Nano-Fabrication of Biodegradable Polymers for Drug Delivery. Advances in Drug Delivery Review, 56, 1621-1633. http://dx.doi.org/10.1016/j.addr.2004.05.002

[4] Mishra, B., Patel, B.B. and Tiwari, S. (2010) Colloidal Nanocarriers: A Review on Formulation Technology, Types and Applications toward Targeted Drug Delivery. Nanomedicine: Nanotechnology, Biology and Medicine, 6, 9-24. 
http://dx.doi.org/10.1016/j.nano.2009.04.008

[5] Yoo, J.W., Doshi, N. and Mitragotri, S. (2011) Adaptive Micro and Nanoparticles: Temporal Control over Carrier Properties to Facilitate Drug Delivery. Advances in Drug Delivery Review, 63, 1247-1256. http://dx.doi.org/10.1016/j.addr.2011.05.004

[6] Severino, P., Santana, M.H.A., Pinho, S.C. and Souto, E.B. (2011) Polímeros sintéticos biodegradáveis: Matérias-primas e métodos de produção de micropartículas para uso em drug delivery e liberação controlada Polímeros, 21, 286-292.

http://dx.doi.org/10.1590/S0104-14282011005000060

[7] Giri, T.K., Choudhary, C., Ajazuddin., Alexander, A., Badwaik, H. and Tripathi, D.K. (2013) Prospects of Pharmaceuticals and Biopharmaceuticals Loaded Microparticles Prepared by Double Emulsion Technique for Controlled Delivery. Saudi Pharmaceutical Journal, 21, 125-141. http://dx.doi.org/10.1016/j.jsps.2012.05.009

[8] Woodruff, M.A. and Hutmacher, D.W. (2010) The Return of a Forgotten Polymer: Polycaprolactone in the 21st Century. Progress in Polymer Science, 35, 1217-1256.

http://dx.doi.org/10.1016/j.progpolymsci.2010.04.002

[9] Dash, T.K. and Konkimalla, B. (2012) Poly- $\epsilon$-Caprolactone Based Formulations for Drug Delivery and Tissue Engineering: A Review. Journal of Controlled Release, 158, 15-33. http://dx.doi.org/10.1016/j.jconrel.2011.09.064

[10] Campos, A., Teodoro, K.B.R., Marconcini, J.M., Mattoso, L.H.C. and Franchetti, S.M.M. (2011) Efeito do Tratamento das Fibras nas Propriedades do Biocompósito de Amido Termoplástico/Policaprolactona/Sisal. Polímeros, 21, 217-222. http://dx.doi.org/10.1590/S0104-14282011005000039

[11] Sinha, V.R., Bansal, K., Kaushik, R., Kumria, R. and Trehan, A. (2004) Poly- $\varepsilon$-Caprolactone Microspheres and Nanospheres: An Overview. International Journal of Pharmaceuticals, 278, 1-23.

[12] Buttini, F., Soltani, A., Colombo, P., Marriott, C. and Jones, S.A. (2008) Multilayer PVA Adsorption onto Hydrophobic Drug Substrates to Engineer Drug-Rich Microparticles. European Journal of Pharmaceutical Sciences, 33, 20-28. http://dx.doi.org/10.1016/j.ejps.2007.09.008

[13] Kesel, C., Lefèvre, C., Nagy, J.B. and David, C. (1999) Blends of Polycaprolactone with Polyvinylalcohol: A DSC, Optical, Microscopy and Solid State NMR Study. Polymer, 40, 19691978. http://dx.doi.org/10.1016/S0032-3861(98)00253-5

[14] Ibraheem, D., Iqbal, M., Agusti, G., Fessi, H. and Elaissari, A. (2014) Effects of Process Parameters on the Colloidal Properties of Polycaprolactone Microparticles Prepared by Double Emulsion Like Process. Colloids and Surfaces A: Physicochemical and Engineering Aspects, 445, 79-91. http://dx.doi.org/10.1016/j.colsurfa.2014.01.012

[15] Yang, Y.Y., Chung, T.S. and Ng, N.P. (2001) Morphology, Drug Distribution, and in Vitro Release Profiles of Biodegradable Polymeric Microspheres Containing Protein Fabricated by Double-Emulsion Solvent Extraction/Evaporation Method. Biomaterials, 22, 231-241. http://dx.doi.org/10.1016/S0142-9612(00)00178-2

[16] Roa, J.P.B., Mano, V., Faustino, P.B., Felix, E.B., Silva, M.E.S.R. and Filho, J.D.S. (2010) Síntese e caracterização do copolímero poli(3-hidroxibutirato-co- $\varepsilon$-caprolactona) a partir de poli(3-hidroxibutirato) e poli( $\varepsilon$-caprolactona). Polímeros, 20, 221-226. http://dx.doi.org/10.1590/S0104-14282010005000038

[17] Bikiris, D.N. (2013) Nanocomposites of Aliphatic Polyesters: An Overview of the Effect of Different Nanofillers on Enzymatic Hydrolysis and Biodegradation of Polyesters. Polymer Degradation and Stability, 98, 1908-1928. 
http://dx.doi.org/10.1016/j.polymdegradstab.2013.05.016

[18] Aguzzi, C., Cerezo, P., Viseras, C. and Caramella, C. (2007) Use of Clays as Drug Delivery Systems: Possibilities and Limitations. Applied Clay Science, 36, 22-36. http://dx.doi.org/10.1016/j.clay.2006.06.015

[19] Salihi, E.Ç. and Mahramanlığlu, M. (2014) Equilibrium and Kinetic Adsorption of Drugs on Bentonite: Presence of Surface Active Agents Effect. Applied Clay Science, 101, 381-389. http://dx.doi.org/10.1016/j.clay.2014.06.015

[20] Dornelas, C.B., Rezende, D.K., Rocha, H.V.A., Gomes, A.S, Tavares, M.I.B., Coutinho, S.S.S. and Cabral, L.M. (2008) Avaliação de Derivados Poliméricos Intercalados em Montmorilonita Organofílica na Preparação de Novos Materiais de Uso Farmacêutico, Polímeros, 18, 222-229. http://dx.doi.org/10.1590/S0104-14282008000300007

[21] Bordes, P., Pollet, E. and Avérous, L. (2009) Nano-Biocomposites: Biodegradable Polyester/Nanoclay System. Progress in Polymer Science, 34, 125-155.

http://dx.doi.org/10.1016/j.progpolymsci.2008.10.002

[22] Sapalidis, A.A., Katsaros, F.K., Steriotis, Th.A., Kanellopoulus, N.K. (2012) Properties of Poly(Vinyl-Alcohol)-Bentonite Clay Nanocomposites Films in Relation to Polymer-Clay Interactions. Journal of Applied Polymer Science, 123, 1812-1821. http://dx.doi.org/10.1002/app.34651

[23] Yeun, J.H., Bang, G.S., Park, B.J., Ham, S.K. and Chang, J.H. (2006) Poly(Vinyl Alcohol) Nanocomposite Films: Thermooptical Properties, Morphology, and Gas Permeability. Journal of Applied Clay Science, 101, 591-596. http://dx.doi.org/10.1002/app.23372

[24] Dong, Y and Feng, S.S. (2005) Poly(D,L-Lactide-co-Glycolide)/Montmorillonite Nanoparticles for Oral Delivery of Anticancer Drugs. Biomaterials, 26, 6068-6076.

http://dx.doi.org/10.1016/j.biomaterials.2005.03.021

[25] Dyab, A.K.F., Al-Lohedan, H.A. Essawy, H.A., Abd El-Mageed, A.I.A. and Taha, F. (2014) Fabrication of Core/Shell Hybrid Organic-Inorganic Polymer Microspheres via Pickering Emulsion Polymerization Using Laponite Nanoparticles. Journal of Saudi Chemical Society, 18, 610-617. http://dx.doi.org/10.1016/j.jscs.2011.12.008

[26] Imbrogno, A., Piacentini, E., Drioli, E. and Giorno, L. (2014) Preparation of Uniform PolyCaprolactone Microparticles by Membrane Emulsification/Solvent Diffusion Process. Journal of Membrane Science, 467, 262-268. http://dx.doi.org/10.1016/j.memsci.2014.05.037

[27] Severino, S., Santana, M.H.A., Pinho, S.C. and Souto, E.B. (2011) Polímeros sintéticos biodegradáveis: Matérias primas e Métodos de produção de micropartículas para uso em Drug Delivery e Liberação Controlada. Polímeros, 21, 286-282. http://dx.doi.org/10.1590/S0104-14282011005000060

[28] Goes, A.M., Carvalho, S., Oréfice, R.L., Avérous, L., Custódio, T.A., Pimenta, J.G., Souza, M.B., Branciforti, M.C. and Bretas, R.E.S. (2012) Viabilidade Celular de Nanofibras de Polímeros Biodegradáveis e seus Nanocompósitos com Argila Montmorilonita. Polímeros, 22, 34-40. http://dx.doi.org/10.1590/S0104-14282012005000012

[29] Cruz, A.C., Meireles, C.S., Ribeiro, S.D., Filho, G.R., Assunção, R.M.N., Cerqueira, D.A., Zeni, M. and Poletto, P. (2011) Utilização do acetato de celulose produzido a partir da celulose extraída do caroço de manga como matriz para produção de sistemas microparticulados. Química Nova, 34, 385-389. http://dx.doi.org/10.1590/S0100-40422011000300004

[30] Winzenburg, G., Schmidt, M., Fuchs, S. and Kissel, T. (2004) Biodegradable Polymers and Their Potential Use in Parenteral Veterinary Drug Delivery Systems. Advanced Drug Delivery Reviews, 56, 1453-1466. http://dx.doi.org/10.1016/j.addr.2004.02.008 
[31] Dhanaraju, M.D., Gopinath, D., Ahmed, M.R., Jayakumar, R. and Vamsadhara, C. (2006) Characterization of Polymeric Poly ( $\varepsilon$-Caprolactone) Injectable Implant Delivery System for the Controlled Delivery of Contraceptive Steroids. Journal of Biomedical Material Research, 76A, 63-72. http://dx.doi.org/10.1002/jbm.a.30458

[32] Suave, J., Dall'agnol, E.C., Pezzin, A.P.T., Silva, D.A.K., Meier, M.M. and Soldi, V. (2006) Microencapsulação: Inovação em diferentes áreas. Health and Environment Journal, 7, 1220.

[33] Kemala, T., Budianto, E. and Soegiyono, B. (2012) Preparation and Characterization of Microspheres Based on Blend of Poly(Lactic Acid) and Poly( $\varepsilon$-Caprolactone) with Poly(Vinyl Alcohol) as Emulsifier. Arabian Journal of Chemistry, 5, 103-108. http://dx.doi.org/10.1016/j.arabjc.2010.08.003

[34] Monteiro, M.S.S.B., Rodrigues, C.L., Neto, R.C. and Tavares, M.I.B. (2012) The Structure of Polycaprolactone-Clay Nanocomposites Investigated by ${ }_{1} \mathrm{H}$ NMR Relaxometry. Journal of Nanoscience and Nanotechonology, 12, 7307-7313. http://dx.doi.org/10.1166/jnn.2012.6431

[35] Brandolini, A.J. and Hills, D.D. (2000) NMR Spectra of Polymers and Polymer Additives. Marcel Dekker Inc., New York.

[36] Holzgrabe, U., Wawer, I and Diehl, B. (2008) NMR Spectroscopy in Pharmaceutical Analysis. Elsevier, Germany.

[37] Junior Canevarolo, S.V. (2007) Técnicas de Caracterização de Polímeros. Artliber, São Paulo.

[38] Skoog, D.A., Holler, F.J. and Nieman, T.A. (2002) Princípios de Análise Instrumental. Bookman, Porto Alegre.

[39] Dal Bosco, S.M., Jimenez, R.S., Vignado, C., Fontana, J., Geraldo, B., Figuereido, F.C.A., Mandelli, D. and Carvalho, W.A. (2006) Removal of Mn(II) and Cd(II) from Wastewaters by Natural and Modified Clays. Adsorption, 12, 133-146.

http://dx.doi.org/10.1007/s10450-006-0375-1

[40] Huang, J.M. and Yang, S.J. (2005) Studying the Miscibility and Thermal Behavior of Polybenzoxazine/Poly( $\varepsilon$-Caprolactone) Blends Using DSC, DMA, and Solid State ${ }^{13} \mathrm{C}$ NMR Spectroscopy. Polymer, 46, 8068-8078. http://dx.doi.org/10.1016/j.polymer.2005.06.104

[41] Pedroza, O.J.O. and Tavares, M.I.B.T. (2004) Pré-Tratamento Físico: Um Procedimento Importante para o Aumento na Resolução Espectral em Estudos de Microestrutura de Polímeros por $\mathrm{RMN}^{13} \mathrm{C}$ em Solução. Polímeros, 14, 265-266. http://dx.doi.org/10.1590/S0104-14282004000400012

[42] Spevacek, J., Brus, J., Divers, T. and Grohens, Y. (2007) Solid-State NMR Study of Biodegradable Starch/Polycaprolactone Blends. European Polymer Journal, 43, 1866-1875. http://dx.doi.org/10.1016/j.eurpolymj.2007.02.021

[43] Ray, S.S. and Bousmina, M. (2005) Biodegradable Polymers and Their Layered Silicate Nanocomposites: In Greening the 21st Century Materials World. Progress in Materials Science, 50, 962-1079. http://dx.doi.org/10.1016/j.pmatsci.2005.05.002

[44] da Silva, N.M. and Tavares, M.I.B. (1998) Solid State NMR Study of Poly(Methyl Methacrylate)/Polyvinylpyrrolidone Blends. Polymer Bulletin, 41, 307-310. http://dx.doi.org/10.1007/s002890050367

[45] Elzein, T., Nasser-Eddine, M., Delaite, C., Bistac, S. and Dumas. P.J. (2004) FTIR Study of Polycaprolactone Chain Organization at Interfaces. Journal of Colloids and Interface Science, 273, 381-387. http://dx.doi.org/10.1016/j.jcis.2004.02.001

[46] Li, R., Nie, K., Shen, X. and Wang, S. (2007) Biodegradable Polyester Hybrid Nanocomposites Containing Titanium Dioxide Network and Poly( $\varepsilon$-Caprolactone): Synthesis and Cha- 
racterization. Materials Letters, 61, 1368-1371.

http://dx.doi.org/10.1016/j.matlet.2006.07.032

[47] Yu, Y.H., Lin, C.Y., Yeh, M.J. and Lin, W.H. (2003) Preparation and Properties of Poly(Vinyl Alcohol)-Clay Nanocomposite Materials. Polymer, 44, 3553-3560.

http://dx.doi.org/10.1016/S0032-3861(03)00062-4

[48] Stulzer, H.K., Tagliari, M.P., Silva, M.A.S. and Laranjeira, M.C.M. (2007) Desenvolvimento, Avaliação e Caracterização Físico Química de Micropartículas Constituídas de Aciclovir/ Quitosana Desenvolvidas pela Técnica de Spray-drying. Latin American Journal of Pharmacy, 26, 866-871.

[49] Borsacchi, S., Geppi, M., Ricci, L., Ruggeri, G. and Veracini, C.A. (2007) Interactions at the Surface of Organophilic-Modified Laponites: A Multinuclear Solid-State NMR Study. Langmuir, 23, 3953-3960. http://dx.doi.org/10.1021/la063040a

[50] Li, R., Nie, K., Pang, W. and Qingren, Z. (2007) Morphology and Properties of OrganicInorganic Hybrid Materials Involving $\mathrm{TiO}_{2}$ and Poly( $\varepsilon$-Caprolactone), a Biodegradable Aliphatic Polyester. Journal of Biomedical Material Research Part A, 83A, 114-122. http://dx.doi.org/10.1002/jbm.a.31224

[51] Guerrini, L.M., Branciforti, M.C. and Bretas, R.E.S. (2006) Eletrofiação do Poli(álcool vinílico) Via Solução Aquosa. Polímeros, 16, 286-293. http://dx.doi.org/10.1590/S0104-14282006000400007

[52] Dobry, D.E., Settell, D.M., Baumann, J.M., Ray, R.J., Graham, L.J. and Beyerinck, R.A. (2009) A Model-Based Methodology for Spray-Drying Process Development. Journal of Pharmaceutical Innovation, 4, 133-142. http://dx.doi.org/10.1007/s12247-009-9064-4

[53] Shu, B., Yu, W., Zhao, Y. and Liu, X. (2006) Study on Microencapsulation of Lycopene by Spray-Drying. Journal of Food Engineering, 76, 664-669. http://dx.doi.org/10.1016/j.jfoodeng.2005.05.062

[54] Florido, D.M. (2013) Produção de Microesferas de Nanocompósitos de Quitosano e Argila para Libertação Controlada de Fármacos Dissertação para obtenção do Grau de Mestre em Engenharia Biomédica. Universidade Nova de Lisboa, Lisboa, 95 p.

[55] Camargo, P.H.C., Satyanarayana, K.G. and Wypych, F. (2009) Nanocomposites: Synthesis, Structure, Properties and New Application Opportunities. Materials Research, 12, 1-39.

[56] Buttini, F., Colombo, P., Wenger, M.P.E., Mesquita, P., Marriott, C. and Jones, S.A. (2008) Back to Basics: The Development of a Simple, Homogenous, Two-Component Dry-Powder Inhaler Formulation for the Delivery of Budesonide Using Miscible Vinyl Polymers. Journal of Pharmaceutical Sciences, 97, 1257-1267. http://dx.doi.org/10.1002/jps.21126

[57] Furukawa, Y., Watkins, J.L., Kim, J., Curry, K.J. and Bennett, R.H. (2009) Aggregation of Montmorillonite and Organic Matter in Aqueous Media Containing Artificial Seawater. Geochemical Transactions, 10, 1-11.

[58] Esposito, E., Drechsler, M., Mariani, P., Sivieri, E., Bozzini, R., Montesi, L., Menegatti, E. and Cortesi, R. (2007) Nanosystems for Skin Hydration: A Comparative Study. International Journal of Cosmetic Science, 29, 39-47. http://dx.doi.org/10.1111/j.1467-2494.2007.00362.x

[59] Teixeira-Neto, E. and Teixeira-Neto, A.A. (2009) Modificação química de argilas: Desafios científicos e tecnológicos para obtenção de novos produtos com maior valor agregado. Química Nova, 32, 809-817. http://dx.doi.org/10.1590/S0100-40422009000300023

[60] Dornelas, C.B., Rezende, D.K., Tavares, M.I.B., Gomes, A.S. and Cabral, L.M. (2008) Preparation and Reactional Evaluation of Formation of PVP K-30-Montmorillonite (Natural and Organophilic) by X Ray Diffraction. Polímeros, 18, 187-192. 
http://dx.doi.org/10.1590/S0104-14282008000200017

[61] Dornelas, C.B., Grillo, L.A.M., Junior, I.D.B., Nascimento, T.G., Resende, D.K., Tavares, M.I.B., Gomes, A.S., Junior, A.M. and Cabral, L.M. (2010) Estudo do Processo de Intercalacao via Solucao PVP-Bentonita. A Avaliação da Influencia do Tempo Reacional, da Proporção de Polimero-argila e da Massa Molar Media. Polímeros, 20, 275-279. http://dx.doi.org/10.1590/S0104-14282010005000047

[62] Pohlmann, A.R., Weiss, V., Mertins, O., Silveira, N.P. and Guterres, S.S. (2002) Spray-Dried Indomethacin-Loaded Polyester Nanocapsules and Nanospheres: Development, Stability Evaluation and Nanostructure Models. European Journal of Pharmaceutical Science, 16, 305-312. http://dx.doi.org/10.1016/S0928-0987(02)00127-6

[63] Porte, L.H.M., Leão, M.H.M.R and Porte, A. (2011) Avaliação da porosidade de microcápsulas contendo proteína bioativa por porosimetria de mercúrio e adsorção de nitrogênio. Química Nova, 34, 1582-1587. http://dx.doi.org/10.1590/S0100-40422011000900018

\section{Submit or recommend next manuscript to SCIRP and we will provide best service} for you:

Accepting pre-submission inquiries through Email, Facebook, LinkedIn, Twitter, etc. A wide selection of journals (inclusive of 9 subjects, more than 200 journals)

Providing 24-hour high-quality service

User-friendly online submission system

Fair and swift peer-review system

Efficient typesetting and proofreading procedure

Display of the result of downloads and visits, as well as the number of cited articles Maximum dissemination of your research work

Submit your manuscript at: http://papersubmission.scirp.org/

Or contact msa@scirp.org 